\title{
COVID-19 Impact on Medical Education: Evidence of International Students
}

\author{
Natalia Mospan ${ }^{1, *}$, Valentyna Slipchuk² \\ ${ }^{1}$ Department of English Philology and Translation, Faculty of Philology, Borys Grinchenko Kyiv University, 04212, Kiev, Ukraine \\ ${ }^{2}$ Department of Medical and General Chemistry, Pharmaceutical Faculty, Bogomolets National Medical University, \\ 01601, Kiev, Ukraine
}

Received October 6, 2020; Revised December 11, 2020; Accepted December 18, 2020

\section{Cite This Paper in the following Citation Styles}

(a): [1] Natalia Mospan, Valentyna Slipchuk, "COVID-19 Impact on Medical Education: Evidence of International Students," Universal Journal of Educational Research, Vol. 8, No. 12B, pp. 8393-8401, 2020. DOI: 10.13189/ujer.2020.082645.

(b): Natalia Mospan, Valentyna Slipchuk (2020). COVID-19 Impact on Medical Education: Evidence of International Students. Universal Journal of Educational Research, 8(12B), 8393-8401. DOI: 10.13189/ujer.2020.082645.

Copyright $\bigcirc 2020$ by authors, all rights reserved. Authors agree that this article remains permanently open access under the terms of the Creative Commons Attribution License 4.0 International License

\begin{abstract}
The study explores higher medical education transformation during the COVID-19 pandemic in the world and Ukraine. It also highlights the current trends coronavirus quarantine and digitalization of medical education. The article also aims to study international medical students' needs and perspectives on the eve of quarantine and their attitude to remote learning during the COVID-19 pandemic in spring 2020. The research is based on surveys of first-year international medical students, chosen at random. It allowed students to provide feedback on their country of origin, satisfaction, ways of financing the study, and future career plans, as well as their attitude to remote learning during the COVID-19 pandemic. The qualitative data analysis lets advocate that coronavirus has determined a deep transformation in higher medical education and affected international medical student population. First, coronavirus has changed the role of medical students and internship. Second, it has fastened transition from traditional to digitally-based education and brought distance learning and exams worldwide. On the eve of the quarantine, Ukraine is becoming a host country for international students primarily from Asia and Africa. Among the reasons for international students' choice of Ukraine as a place for study are their country preference, high-quality education, friends' advice and geographical location. The international medical students consider Ukraine not only as a high-quality medical education provider but as the perspective country for postgraduate employment. Besides, the majority of first-year international medical students find remote learning during
\end{abstract}

the COVID-19 pandemic supporting, effective but tiring. The research creates a paradigm for future studies of the international medical students' phenomenon.

Keywords The COVID-19 pandemic, International Medical Students, Higher Medical Education, Medical Universities, Remote Learning

\section{Introduction}

Globalization and internationalization have resulted in increasing the international students' population, predominantly in medical education, that has been granted exceptional status. "Europe has around 440 medical schools that produce 70,000 medical graduates every year" [1] (p. 3). Medical schools in England manage to fill up to $7.5 \%$ of their places with overseas students from outside of the European Union. These students pay the full cost of their tuition and living costs at medical school [2] (p. 6). According to the BMA (British Medical Association) report for 2014-2015 "international students paid an estimated $£ 4.8$ billion in tuition fees to UK universities. That accounts for over $14 \%$ of total university income. Some $88 \%$ - $£ 4.2$ billion - of this fee income was paid by students from outside the EU" [3] (p. 2). The authors of the report warn that any reduction in the number of non-EU students at UK medical schools has significant implications for medical school funding, as non-EU 
students pay from $£ 25,000$ to $£ 35,000$ per year in England [3].

However, the two latest factors as Brexit and COVID-19 pandemic put at risk the increase of the international students' population in the leading host countries in the future. Although in 2018 the overall number of $\mathrm{EU}$ applicants in the UK was static $-6,610$, their number fell from 1,800 to 1,660 for medicine. Busby [4] states that "the fall comes despite the government's confirmation in July that EU students enrolling in English universities in the first academic year after Brexit will pay the same tuition fees as British students". Ross [5] expects that the COVID-19 pandemic will redistribute international student flows in the following way: New Zealand will increase its share of globally mobile students by $1 \%$, and Australia by $2 \%$ due to the rapid suppression of the coronavirus.

Besides that, digitalization in higher education as an impact factor promotes the change of the international student flows map in the world as well. According to the official sites of EduCanada and Studying in the UK and Coronavirus (COVID-19), their national universities are currently providing programs online. UK universities offer hybrid learning - digital lectures and seminars, and face-to-face tuition [6]. Based on the said above, this research focuses on the COVID-19 impact on medical education for international students predominantly in Ukraine, as a host country for international medical students.

\section{Materials and Methods}

\subsection{Research Focus}

It should be noted, though, that this article focuses on several levels of analysis: geographical and chronological. First, there is an attempt to provide an overview of the international and national medical education transformation on the eve and during the COVID-19 pandemic. Second, the article also aims to shed light on international medical students' needs and perspectives on the eve of quarantine and their attitude to remote learning during the COVID-19 pandemic. The research questions were: What changes has medical education undergone during the COVID-19 pandemic? Why do international students choose Ukraine for medical education? What are their needs and employment perspectives? How do international medical students find remote learning during the COVID-19 pandemic?

The research objectives were identified through the following primary methods: 1 ) theoretical literature review of the existing materials available on that problem: in particular, publications, educational reports, and legislative documents; official sites of medical universities in Ukraine; 2) two quantitative student surveys were designed and conducted for data collecting for this article. The 1-st survey aimed at researching international medical students' needs and perspectives on the eve of the quarantine. The 2-nd survey studied their experience at remote learning during the COVID-19 pandemic. A technique of simple random sampling enabled getting data from a sample.

A theoretical literature review makes it possible to analyze international and national educational policy on the eve and during the COVID-19 pandemic. The view of official sites of Ukrainian medical HEIs allows collecting data of the quantity of international medical students for 2014-2020. Moreover, the official university sites viewing contributes to examining education technology tools provided during the COVID-19 pandemic.

\subsection{Implementation and Participants}

Two different quantitative student surveys were designed in Google Forms format and conducted online in Bogomolets National Medical University in 2019-2020. The first 10-question online questionnaire was administered online for the first-year international medical students (at random) during the academic year, September and March 2019-2020. As one part of the first-year international students is doing the course in English and the other part - in Ukrainian, the questionnaire was provided in English (139 responses) and in Ukrainian (12 responses). As a result, this survey is based on responses from 151 first-year international medical students in Bogomolets National Medical University in 2019. The second online questionnaire was administered online for the first-year international medical students (at random) in English during the COVID-19 pandemic in March-May, 2020. The questionnaire was responded to by 40 students. The surveys allowed students to provide feedback on their country of origin, preferences, educational background, needs, experience, satisfaction with educational services at the host institution, ways of financing the study, and their future career plans, as well as their attitude to remote learning during the COVID-19 pandemic. On the example of one medical university, the surveys contribute a lot to developing solution on the current state of play of international student population in national medical education.

The collected data and questionnaire responses were analyzed using qualitative and quantitative methods. For the questionnaires responses analysis, the collected data was calculated, summarized and presented in tables and diagrams for better visual perception.

\section{Results}

\subsection{Trends in International Medical Education Transformation during COVID-19 Pandemic}

The COVID-19 pandemic has caused quantitative and 
qualitative changes in international medical education worldwide. First, it affects international medical students. According to UNICEF monitoring, 177 countries are currently implementing nationwide closures, impacting about $73.5 \%$ of the world's student population. As evidenced by Mugambi [7], "foreign students in the UK are fleeing the country". Besides, they have faced postponement of programs, suspension of examinations, delay in the start of classes, extended deadlines for admissions, blocking at hostels, financial and employment problems, and others. "International students have been living with the daily reality of COVID-19... worried about being unable to return to their home countries due to the travel bans" [7].

Second, the COVID-19 pandemic has brought a great challenge to HEIs - an urgent transition to distance learning. Distance learning has become the only solution to continue the educational process during periods of schools and HEIs closure. Education systems in the world met that challenge in different conditions. Sá \& Saerpa [8] include, among others, "the suspension of face-to-face classes and student tutorial support". These activities began to be provided "via the Internet, in a context in which digital... classes became the only means of interaction between teachers and students" [8]. Though distance learning was not an unknown phenomenon in higher education. As shows the World Economic Forum COVID Action Platform [9]:

"Even before COVID-19, there was already high growth and adoption in education technology, with global EdTech investments reaching US\$18.66 billion in 2019 and the overall market for online education projected to reach $\$ 350$ billion by 2025 . Whether it is language apps, virtual tutoring, video conferencing tools, or online learning software, there has been a significant surge in usage since COVID-19".

Taking into account, that "transitioning to online learning at scale is very difficult and highly complex undertaking for education systems, even in the best of circumstances" [10], authoritative world organizations "gave a helping hand" to education systems in the world. The UNESCO has recommended "the list of educational applications, platforms, and resources" to facilitate student learning and provide social care and interaction during quarantine [11]. The World Bank Group has offered guidance note on remote learning "to maximize countries' effectiveness in designing and executing remote learning" [12]. In that way, the COVID-19 pandemic has fastened the digitalization of education worldwide.

Higher medical education has gained a great experience from both the COVID-19 pandemic and remote learning. First, coronavirus has brought live medical student participation in patient care services. While some authors $[13,14]$ argue the role of medical students during the COVID-19 pandemic, others $[15,16,17]$ believe, that it gives huge professional experience for a future doctor. For example, Miller [13] concerns that "medical students acting solely as learners introduce unnecessary risks for patients and other clinicians", and Menon et al. [14] consider medical students "not essential workers". On the other hand, Galagher et al. [15] believe that the "risk of students' and trainees' involvement in the care of infectious patients" is small and that the Covid-19 pandemic will make medical students better doctors. In the USA, as Smith [16] states, "students graduating from the medical school have been called upon to volunteer or work in hospitals before their time in medical school was over". In the UK, medical students were involved in a multidisciplinary team to solve virtually "some of the most pressing issues faced by those tackling the Covid-19 pandemic" [17]

Second, remote learning has transformed traditional face-to-face medical education to a digitally-based format, bringing to medical universities videoconferences, small group teaching with precautions, e-learning modules and "archived surgical videos with technical pointers from experienced faculty and usage of surgical simulators" [18].

\subsection{Trends in Medical Education on the Eve of Coronavirus in Ukraine}

Since the Bologna Process entering in 2005, the modernization of the Ukrainian higher education system has been launched. The main problem of this modernization is to reach a compromise between national higher education traditions and the challenges of globalization, internationalization, and Europeanization. Since then, significant changes have happened in national higher medical education. Among them are higher education democracy, medical university autonomy, changes in graduates' employment policy, master programs, Ukrainian diplomas recognition in the world, the national medical universities entry into the international rankings, academic staff training on the British Council programs, and increasing the number of international students.

The international students' availability has become a part of national educational policy, and their increasing number in medical universities is one of the promising directions of higher education modernization. Their number has been currently increasing since 2006. In 2014 2015, in Ukrainian HEIs 21389 international students studied from 124 countries. Despite war and economic uncertainty, international students flood Ukraine every year. In 2016 the top providers of foreign students to national universities were Azerbaijan, Turkmenistan, India, Nigeria, Morocco, Georgia, Jordan, Iraq, China, and Uzbekistan. In 2017 64,000 foreigners attended national universities. In most instances, a cheap education attracts them a lot as Ukrainian medical schools cost from $\$ 3,000$ to $\$ 5,000$ per year [19]. 
Table 1. Foreign students number increase in medical universities in Ukraine in 2014-2020

\begin{tabular}{lcccc}
\hline № & Medical University & $\mathbf{2 0 1 4 - 2 0 1 5}$ & $\mathbf{2 0 1 9 - 2 0 2 0}$ & Programs \\
\hline 1 & Kharkiv National Medical University & 3296 & 2100 & Medicine, Dentistry \\
2 & Odessa National Medical University & 2553 & 1000 & Internal medicine, Dentistry, Pharmacy \\
3 & National Pirogov Memorial Medical University, Vinnytsya & 1897 & 2080 & Medicine, Dentistry, Pharmacy \\
4 & Zaporizhzhya State Medical University & 1761 & 2850 & Medicine, Dentistry, Pharmacy \\
5 & Ivano-Frankivsk National Medical University & 1727 & 1594 & Medicine, Dentistry, Pharmacy \\
6 & Dnipropetrovsk State Medical Academy & 1673 & 5000 & Medicine, Dentistry, Pharmacy \\
7 & Bogomolets National Medical University & 1504 & 3160 & Pharmacy, Dentistry, Medicine \\
8 & National University of Pharmacy & 1478 & 100 & Pharmacy \\
9 & I. Horbachevsky Ternopil National Medical University & 1179 & 2000 & Pharmacy, Dentistry, Medicine, Nursing \\
10 & Danylo Halytsky Lviv National Medical University & 1046 & 1334 & General Medicine, Dentistry, Pharmacy \\
11 & Bukovinian State Medical University & 997 & 1800 & Pharmacy, Dentistry, Medicine, Nursing \\
12 & Ukrainian State Medical Dental Academy & 862 & 1400 & Pharmacy, Medicine, Pediatrics, Nursing \\
& Total & 19973 & 24418 & \\
\hline
\end{tabular}

In 2014-2015, 19973 international students obtained professional training in health care in national medical universities. The top 3 countries were India (3943 students), Nigeria (2193 students), and Morocco (1744 students). Twelve national medical universities provide international students with a Master's degree in Health-related programs. In 2019-2020, there were 24418 international medical students in Ukraine compared with 19973 in 2014-2015 (see Table 1).

Since 2015, Bogomolets National Medical University has become a leader in international students' enrolment with the trends in increasing their number in Master and postgraduate programs, taught in English. Thus, in 2015 1513 international students (among them 738 taught in English) were enrolled, in 2016 - 1719 international students (among them 1022 taught in English), in 2017 - all 930 foreigners obtained programs in English. In 2018 2242 , and in 2019 - 3160 international students were enrolled to study at the university.

\subsection{International Medical Students' Needs and Perspectives on the Eve of Quarantine}

The trends in increasing international medical students' population in Ukraine focus our research on studying current needs (country of origin, educational background, course preferences, satisfaction, ways of study funding) and perspectives (future career plans) of international medical students in Bogomolets National Medical University. We strongly believe that the results of one university, situated in the capital of the country, could reflect the general situation in Ukraine. The survey conducted in Bogomolets National Medical University in 2019-2020 shows the following:

1. Enrolment of international students by origin shows that they mainly come from Asia, Africa and former the Soviet Union Republics. Among top countries of origin is India (33\%). Then go Iran (13\%), Egypt and Nigeria (8\%), Morocco (5\%), Ghana and Syria (4\%), Congo and Uzbekistan (3\%). There are also students from Turkey and Russia (2\%), Jerusalem, Palestine and Pamela (1\%), China, Italy and other countries from Africa.

2. The entrance exam provided in the form of an interview requires international students to prove their education background. Applicants should demonstrate their knowledge in Science and be able to communicate in English or Ukrainian. According to the questionnaire, the respondents can speak a foreign language (predominantly English (90\%)) and are good at Science and Mathematics. Among the subjects chosen for the entrance interview are Biology (75\%), Physics (48\%), Chemistry (41\%) and Mathematics (39\%).

3. The entrance interview was provided in English and Ukrainian to choose from. English as a language for communication was chosen by the English-speaking international medical students, who chose the program taught in English - 92,40\% (146 respondents). Ukrainian for the interview was chosen by the non-English-speaking international medical students, who also chose the program taught in Ukrainian $-7,59 \%$ (12 respondents). That shows that English-taught courses and programs are becoming more demanded by foreigners that requires their significant development in future at Bogomolets National Medical University.

4. Ukraine as a country of international medical students' destination for higher medical or pharmaceutical education is chosen due to affordable fees $(49,04 \%)$, friends' advice (36,31\%), geographical location $(25,48 \%)$, high-quality education $(22,30 \%)$ and information about the country $(17,84 \%)$ (see Figure 1). That survey indicates that the main reason for 
study in Ukraine is affordable fees. Moreover, while choosing the country for education, international students rely predominantly on the experience of the previous international student population who are likely to have learned or have visited Ukraine before. They were and are satisfied with high quality medical education. The geographical location of the country plays an important role either as it can be a nice spot for further student or job mobility. However, 19,11\% of respondents choose the option "Others", that means that they have different reasons for study in Ukraine from suggested in the questionnaire.

5. Among the reasons of international students' choice of Bogomolets National Medical University as a place for study are the following: friends' advice and high-quality education $(43,04 \%)$, course information $(32,91 \%)$, affordable fees to study $(25,95 \%)$. That shows that while choosing the university for education, foreigners also rely predominantly on the experience of the previous international student population who are likely to have learned in Bogomolets National Medical University before. They were and are satisfied with high quality medical education at that university. Course information plays an important role as well in attracting new international customers in educational medical services.

6. The most demanded programs by international medical students provided at Bogomolets National Medical University in 2019 are "Medicine" (64\%) and "Dentistry" (30,40\%), while "Pharmacy" (5\%), and "Pediatrics" $(1 \%)$ are the least popular.

7. The way to finance the study by international medical students is predominantly parent's money $(88,46 \%)$.
Although such ways as a bank loan $(6,41 \%)$, personal savings $(2,56 \%)$, student grants $(1,28 \%)$ and state funding $(1,28 \%)$ are less common, nevertheless they also take place.

8. The future career plans of international medical students depend on the country of origin. In total $49 \%$ of all respondents are planning to come back home and be employed there, while $51 \%$ of them have other plans, including those, who are attracted by the EU $(9 \%)$ and Ukraine $(6 \%)$ as a future place of employment. However, the questionnaires show that among the English-speaking international students the majority (51\%) see the employment perspectives at their place of origin, while among the non-English-speaking international students only $25 \%$ of them are planning to be employed at a native country. It is important to note, that only $9 \%$ of the English-speaking respondents consider the EU as their future place of employment vs $33,3 \%$ of the non-English-speaking respondents. Ukraine as a future work destination attracts the majority of the non-English-speaking international students (41,7\%) and the minority of the English-speaking international students $-3,4 \%$. The difference in future career plans of international medical students is explained by the country of origin. The English-speaking international students come predominantly from countries of Asia and Africa, while non-English-speaking international students come from the former Soviet Union Republics. Therefore, for the last ones Ukraine and the EU is likely to be better work destination than the home country from geographical, economic and cultural points of view.

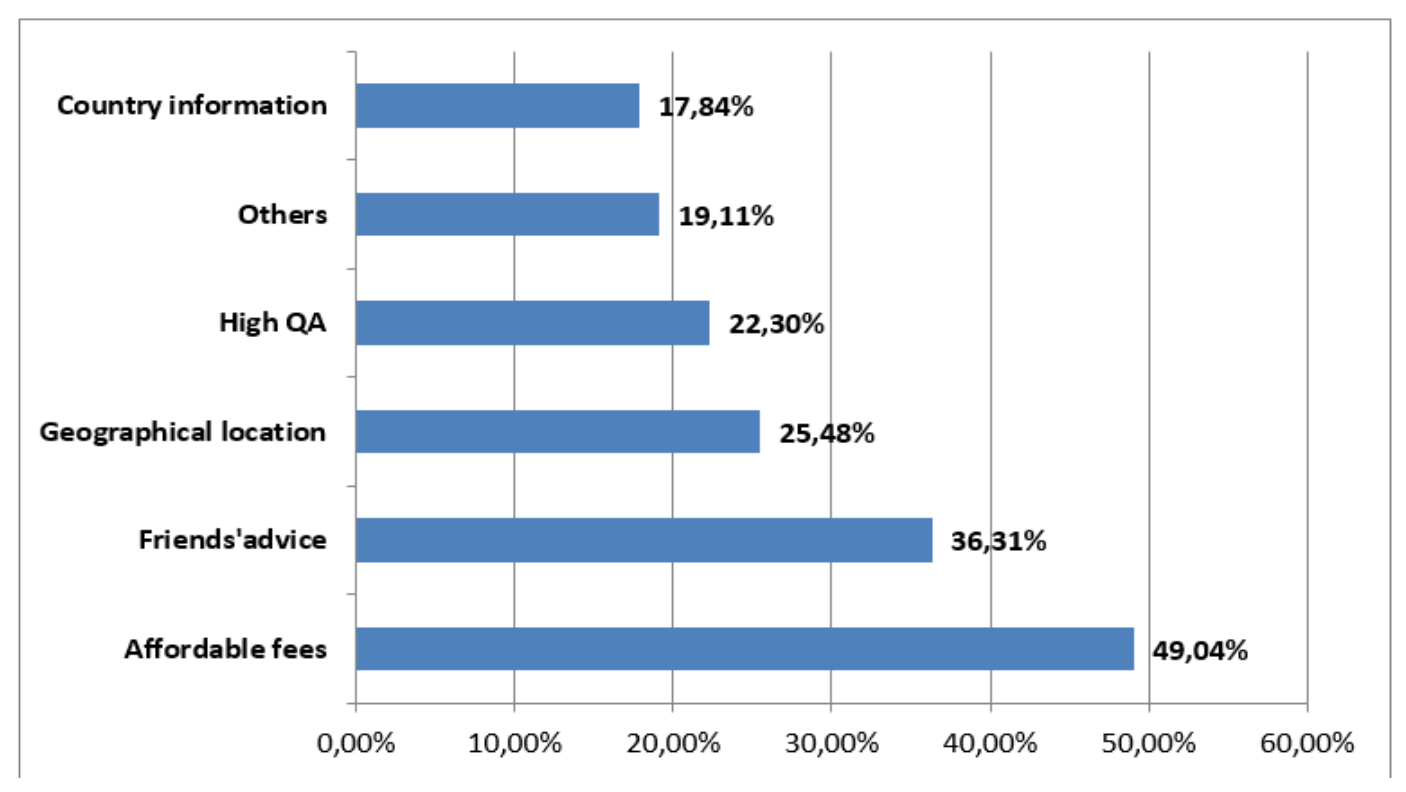

Figure 1. Reasons for higher medical education in Ukraine 
Table 2. EdTech at medical universities in Ukraine during the COVID-19 pandemic

\begin{tabular}{cccc}
\hline № & Medical University in Ukraine & $\begin{array}{c}\text { Digital Learning } \\
\text { Management System }\end{array}$ & $\begin{array}{c}\text { Collaboration } \\
\text { Platform }\end{array}$ \\
\hline 1 & Kharkiv National Medical University & Moodle & BigBlueButton \\
2 & Odessa National Medical University & Moodle & TrueConf \\
3 & National Pirogov Memorial Medical University, Vinnytsya & Office 365 & Microsoft Teams, Google Meet \\
4 & Zaporizhzhya State Medical University & OneDrive, Office 365 & Microsoft Teams, Skype for business \\
5 & Ivano-Frankivsk National Medical University & Office 365 & Microsoft Teams, Skype for business \\
6 & Dnipropetrovsk State Medical Academy & Moodle, Google Classroom & Zoom \\
7 & Bogomolets National Medical University & Neuron & Zoom \\
8 & National University of Pharmacy & Moodle & Zoom \\
9 & I. Horbachevsky Ternopil National Medical University & Moodle & Zoom \\
10 & Danylo Halytsky Lviv National Medical University & MISA, EQX System & Zoom \\
11 & Bukovinian State Medical University & Moodle & Google Meet \\
12 & Ukrainian State Medical Dental Academy & Google Classroom & Zoom \\
\hline
\end{tabular}

\subsection{Medical Education in Ukraine during the COVID-19 Pandemic}

The 2019-2020 academic year was challenging for national medical education. The results need substantial research and analysis. We highlight the main changes in international students' policy the national medical universities had to provide during the quarantine - students' safety, distance learning, internship volunteering and online exams. On the eve of quarantine in Ukrainian medical universities, there were about 24418 international students (see Table 1).

When nationwide quarantine broke out, the universities had to provide safety measures for foreigners. For example, Kharkiv National Medical University introduced a strict pass control to three hostels, where 600 international students resided. The interns of Ivano-Frankivsk National Medical University responded actively to the COVID-19 pandemic, as that region was the most infected. They participated in the examination of patients and worked with medical documentation. The international students of I. Horbachevsky Ternopil National Medical University united to support Ukraine and Ternopil in the fight against the coronavirus. To this end, they raised $5000 \mathrm{UAH}$ to buy medical supplies to protect doctors, disinfectants, and others in need of hospitals. The urgent transition to distance learning allowed national medical universities to continue the educational process effectively. The universities used different EdTech due to their technical and financial opportunities (see Table 2).

According to the report of Zaporizhzhya State Medical University, during coronavirus quarantine, there have been delayed 1,576 online lectures on schedule (26-61 lectures per day), 6,308 classes and conducted 154 exams in 94 disciplines (see http://int.zsmu.edu.ua/new_905.html). However, the educators of Ivano-Frankivsk National Medical University consider that distance learning has certain disadvantages for medical education, mainly in developing practical skills. For instance, in surgery, therapy, infectious diseases, distance learning presents only $30-40 \%$ of learning material, the rest requires practice-oriented classes (see https://www.ifnmu.edu.ua/uk/).

Since 2019-2020 academic year was finishing in the quarantine the procedure of conducting exams required particular online organization and training. The national medical universities provided a mixed format of exams tests at a digital learning management system and online communication (examinee - examiners) at a collaboration platform. Timing (an allocated time for each student's response) allowed to create appropriate conditions for conducting exams online. Before the exams, educators and students had online consultations in terms of detailed instructions on online exam format. For example, in Bogomolets National Medical University, the exam on "General and Inorganic Chemistry" for the first-year students of specialty 226 "Pharmacy, industrial pharmacy" took $90 \mathrm{~min}$. It included a test (20 test-tasks - $30 \mathrm{~min}$ ) and a written part ( 3 tasks required a mandatory motivation, and 2 situational problems - $60 \mathrm{~min}$ ). Ukrainian State Medical Dental Academy conducted practically-oriented exams online in "Dentistry". Successful results proved that all international students gained sufficient professional level. Though, the transition to online exam format did not have negative impacts on learning outputs. All 158 international graduates from Ivano-Frankivsk National Medical University showed high results at exams $-98 \%$. They are fully satisfied with the online organization of educational process and exams. The best graduate at the course said (see https://www.ifnmu.edu.ua/uk/):

"2020 was not an easy year for all of us from the very beginning. We are grateful to the university for organizing everything we need so that we can complete our studies on time."

Accordingly, the COVID-19 pandemic brought essential 
challenges to medical education in Ukraine. However, national medical universities managed to provide educational services online for international students on a satisfactory level.

\subsection{International Medical Students' Attitude to Remote Learning during the COVID-19 Pandemic}

In the era of the CORVID-19 pandemic, student mobility appears at risk of blocking. Digitally-based learning has become the only alternative to continue education during the quarantine. International medical students had to transit rapidly from traditional to digitally-based learning. This experience for the majority of them (79,5\% of the respondents) was new and unexpected. Therefore, to investigate the international medical students' attitude to remote learning during the COVID-19 pandemic another survey was provided in spring 2020.

According to the first-year international medical students' evidence ( $90 \%$ of respondents), the university provided them with EdTech to support access to remote learning during the COVID-19 pandemic. Table 3 presents the most common types of education technology and their frequency of usage.

Table 3 shows that the most common forms of EdTech, that the university used to support access to remote learning are: courses online (62,5\%), e-mailing $(60 \%)$ and texting $(60 \%)$, while digitally-based distance learning (including blended and virtual learning) is less provided $32,5 \%$. The digital learning management system at Bogomolets National Medical University is Neuron, which is widely $(90 \%)$ used during the COVID-19 pandemic. Among collaboration platforms, Zoom was frequently $(92 \%)$ used to support live-video communication. The common MOOCs were Canvas $(46,2 \%)$ and Coursera $(30,8 \%)$. The most popular self-directed learning content among international medical students was YouTube $(74,1 \%)$.

It is important to note that for the majority of respondents $(79,5 \%)$ distance learning was a new experience. Therefore, their perception of distance learning is an essential survey objective. The survey shows that the first-year international medical students' attitude to remote learning during the COVID-19 pandemic is more positive than negative. The majority of respondents $(97,5 \%)$ find it interesting, supporting and effective, while the minority of respondents $(71,8 \%)$ find remote learning tiring, ineffective and dull (see Table 4).

Table 4. International medical students' attitude to remote learning during the COVID-19 pandemic

\begin{tabular}{|c|c|c|c|}
\hline $97,5 \%$ & Positive & Negative & $71,8 \%$ \\
\hline $46,2 \%$ & Interesting & Tiring & $38,5 \%$ \\
$23,1 \%$ & Supporting & Ineffective & $17,9 \%$ \\
$23,1 \%$ & Effective & Dull & $15,4 \%$ \\
$5,1 \%$ & Entertaining & & \\
\hline
\end{tabular}

At remote learning during the COVID-19 pandemic among international medical students, $48,6 \%$ of respondents had no problems, while others:

had poor Internet connection $-43,2 \%$

did not have access to a computer $-10,8 \%$

had no Internet access at home $-8,1 \%$

It must be emphasized, that the majority of the respondents $(71,8 \%)$ have gained new learning experience at remote learning during the COVID-19 pandemic. Another key step of the study was to investigate the knowledge and skills, that the first-year international medical students gained at remote learning during the COVID-19 pandemic (Table 5).

Table 3. EdTech at Bogomolets National Medical University during the COVID-19 pandemic

\begin{tabular}{ccc}
\hline & Education Technology & Frequency \% \\
\hline & & 62,5 \\
Forms of EdTech & Courses online & 60 \\
& E-mailing & 60 \\
Digital learning management systems & Texting & 32,5 \\
& Blended and virtual learning & 90 \\
& Neuron & 45 \\
\hline & Google Classroom & 2,5 \\
\hline & Moodle & 91,7 \\
Collaboration platforms that support live-video communication & Zoom & 20,8 \\
& Google Meet & 16,7 \\
\hline & Skype & 46,2 \\
Massive Open Online Course (MOOC) Platforms & Canvas & 30,8 \\
& Coursera & 23,1 \\
& European Schoolnet Academy & 7,7 \\
\hline & EdEx & 74,1 \\
& YouTube & 33,3 \\
\end{tabular}


Table 5. Skills gained by international medical students at remote learning during coronavirus

\begin{tabular}{ccc}
\hline Skills & Components & $\%$ \\
\hline & Communicate online with groupmates & 53,8 \\
& Communicate online with teachers & 48,7 \\
Digital literacy skills & Manage time for learning and rest & 48,7 \\
& Organize homework (notes) in digital format & 46,2 \\
& Search for educational information & 46,2 \\
& Share educational information / resources with groupmates & 43,6 \\
& Use alternative online educational resources & 28,2 \\
General skills & Collaborate at online classes & 17,9 \\
& Communicative skills & 55,3 \\
& ICT skills & 31,6 \\
& Professional skills & 28,9 \\
& Linguistic skills & 26,3 \\
\hline \multirow{2}{*}{ Soft skills } & Time management & 55,3 \\
& Teamwork & 42,1 \\
& Networking & 42,1 \\
\end{tabular}

According to the first-year international medical students' evidence, the majority of the respondents (see Table 5) have learnt to communicate online with groupmates and teachers, manage time for learning and rest, work in a team, self-study and develop ICT skills at remote learning during the COVID-19 pandemic. However, some of the respondents show that they have not gained any digital literacy skills $(7,7 \%)$, general skills $(15,8 \%)$ and soft skills $(28,9 \%)$. We can assume, that that happened with those respondents who met technical problems with computer or Internet connection at remote learning during the COVID-19 pandemic. Moreover, collaboration at online classes was not a frequent practice.

And the final important question of the survey was to find out the international medical students' perspectives in further formats of education in future. On the one hand, the majority of respondents still prefer the traditional (face-to-face) format of education (73\%), though, on the other hand, they $(70,2 \%)$ choose distance learning (digitally-based learning $(48,6 \%)$ and online courses $(21,6 \%))$. Thus, international medical students have confirmed their readiness for transition to digitally-based learning as a future format of education.

\section{Conclusion}

The COVID-19 pandemic has caused quantitative and qualitative changes in medical education for international students worldwide. The quantitative changes are decreasing of the international student population in leading host countries, risk of blocking of student mobility. The qualitative changes are transition to digitally based education (distance learning and examining provision), active responding of medical students to coronavirus (participation in patient care services and volunteering in hospitals).
On the eve of quarantine, Ukraine has become not only one of the biggest suppliers of international students to the European Union in the EHEA, but it is also a host country for international students primarily from Asia and Africa. Ukraine as a study destination attracts international medical students, first, by high-quality education and then, by affordable tuition fees. English-taught programs are becoming more demanded by international medical students. Some of them even consider Ukraine as a place of future employment.

The coronavirus quarantine has become challenging for national medical education. It has brought similar changes to international medical student service as in the world students safety, distance learning and online exams, internship volunteering in hospitals. The most popular EdTech appliances in national medical universities are Moodle and Zoom. Remote learning provided during the CORVID-19 pandemic does not impact negatively the educational process at medical universities. Though for the majority of the respondents this experience was new and unexpected, they found it supporting and effective. As evidenced by the respondents, at remote learning they have gained in particular digital literacy and soft skills, where communicative and ICT skills, time management, teamwork and self-education are top ones. The main problem they met was a poor Internet connection. Despite their preference of traditional format of learning, the international medical students show their readiness for transition to distance learning in future.

In conclusion we should say, that coronavirus and digitalization cause serious transformation in higher medical education and international medical students population. That requires regular monitoring and special researches from universities and government. We believe that these measures will make benefits in the international university strategy and national educational policy coordination. 


\section{REFERENCES}

[1] Medical Research Education in Europe. Science Policy Briefing, 2012. URL: http://archives.esf.org/fileadmin/ Publicdocuments/Publications/spb46_MedResEurope.pdf

[2] Expansion of Undergraduate Medical Education. A consultation on how to maximize the benefits from the increases in medical student numbers. Gov.UK, Department of Health, 2017. URL: https://assets.publishin g.service.gov.uk/government/uploads/system/uploads/attac hment_data/file/600835/Medical_expansion_rev_A.pdf

[3] Migration Advisory Committee Call for Evidence: the impact of international students in the UK, 2017. URL: https://www.bma.org.uk/-/media/files/pdfs/collective $\% 20 \mathrm{v}$ oice/influence/

uk\%20governments/consultation-response-mac-students-c ommission-august-2017.pdf?la=en

[4] Busby, E. Number of EU applicants to UK medical schools falls to lowest point in decade, figures show. Independent, October 25, 2018.

[5] Ross, J. Pandemic to redistribute international student flows: report. The World University Rankins. June 24, 2020. URL: https://www.timeshighereducation.com/news/pandemic-re distribute-international-student-flows-report

[6] Studying in the UK and Coronavirus (COVID-19). URL: https://www.studyin-uk.com/studying-in-the-uk-coronavir us/

[7] Mugambi, M.M. COVID-19 Pandemic and International Students Abroad. Research, Innovation and Enterprise Blog. University of Nairobi, 2020. URL: https://uonresearch.org/blog/covid-19-pandemic-and-intern ational-students-abroad/

[8] Sá, M. J., Saerpa, S. COVID-19 and the Promotion of Digital Competences in Education, Universal Journal of Educational Research, Vol. 8, № 10, pp.4520-4528, 2020. DOI: $10.13189 /$ ujer.2020.081020.

[9] The COVID-19 pandemic has changed education forever. The World Economic Forum COVID Action Platform. URL:

https://www.weforum.org/agenda/2020/04/coronavirus-ed ucation-global-covid19-online-digital-learning/
[10] Rapid Response Briefing Note: Remote Learning and COVID-19 Outbreak (English). (2020/03/16). Washington, D.C.: World Bank Group. URL: http://documents.worldba nk.org/curated/en/266811584657843186/Rapid-ResponseBriefing-Note-Remote-Learning-and-COVID-19-Outbreak

[11] Distance learning solutions. More on UNESCO's COVID-19 Education Response. URL: https://en.unesco.org/covid19/ educationresponse/solutions

[12] Guidance Note on Remote Learning and COVID-19 (English). (2020/03/03). Washington, D.C.: World Bank Group. URL: http://documents.worldbank.org/curated/en/5 31681585957264427/Guidance-Note-on-Remote-Learning -and-COVID-19

[13] Miller, D.G., Pierson L., Doernberg S. The Role of Medical Students During the COVID-19 Pandemic. Annals of Internal Medicine. Vol. 173, № 2, pp.145-146, 2020. DOI: https://doi.org/10.7326/M20-1281

[14] Menon, A., Klein, E.J., Kollars, K., Kleinhenz, A.W Medical Students Are Not Essential Workers: Examining Institutional Responsibility During the COVID-19 Pandemic. Academic Medicine. Vol. 95, № 8, pp.1149-1151, 2020. DOI: 10.1097/ACM.0000000000003 478

[15] Gallagher, Th.H., Schleyer, A.M. "We Signed Up for This!" - Student and Trainee Responses to the Covid-19 Pandemic. The New England Journal of Medicine. Vol. 382, № 25, p.96, 2020. DOI: 10.1056/NEJMp2005234

[16] Smith L.G. The Covid-19 pandemic will make medical students better doctors. Stat. May 1, 2020. URL: https://www.statnews.com/2020/05/01/the-covid-19-pande mic-will-make-medical-students-better-doctors/

[17] Kinder, F., Harvey A. Covid-19: the medical students responding to the pandemic. BMJ, Vol. 369, p.2160, 2020. DOI: https://doi.org/10.1136/bmj.m2160

[18] Kanneganti A, Sia Ch., Ashokka B., Suat Ooi Sh. B. Continuing medical education during a pandemic: an academic institution's experience. Postgraduate Medical Journal. Vol. 9, pp.384-386, 2020. DOI:10.1136/postgrad medj-2020-137840

[19] Romanenko, M. 64,000 foreigners attend universities in Ukraine. Kyiv Post. Ukraine's Global Voice, February 9, 2017. URL:

https://www.kyivpost.com/ukraine-politics/64000-foreigne rs-attend-universities-ukraine.html 